\title{
Application of AHP (Analytical Hierarchy Process) Method in Inventory Control at PT. Sumber Rezeki Bersama
}

Eko Sumarsono

Program Studi Sistem Informasi, Fakultas Teknik dan Ilmu Komputer, Universitas Potensi Utama

\begin{tabular}{|c|c|}
\hline Article Info & ABSTRACT \\
\hline $\begin{array}{l}\text { Article history: } \\
\text { Received: } 20 / 01 / 2021 \\
\text { Revised: } 03 / 02 / 2021 \\
\text { Accepted: } 28 / 02 / 2021 \\
\text { Available online } 30 / 03 / 2021\end{array}$ & \multirow{2}{*}{$\begin{array}{l}\text { Controlling the amount of inventory value is not an easy thing for } \\
\text { companies, starting from recording the purchase price of goods, } \\
\text { determining prices to presenting these inventories into financial } \\
\text { statements. To facilitate inventory control, a decision support system is } \\
\text { needed that aims to simplify the inventory control process which is } \\
\text { expected to help the problems that exist in the company. The same } \\
\text { thing is needed by PT. Source of Mutual Sustenance. This private } \\
\text { company engaged in the distribution of food products also needs a } \\
\text { decision support system that can control the inventory of goods so as } \\
\text { to facilitate the process of controlling inventory. Previously, inventory } \\
\text { at PT. Sumber Rezeki Bersama experienced problems where the } \\
\text { company did not prioritize ordering goods, especially those with the } \\
\text { highest sales. So that when there are many messages from consumers } \\
\text { for these goods, the company cannot fulfill orders on time, given the } \\
\text { stock of goods that are not always available (because they are not } \\
\text { prioritized). }\end{array}$} \\
\hline $\begin{array}{l}\text { Keywords: } \\
\text { The AHP (Analytical Hierarchy } \\
\text { Process, } \\
\text { Inventory, } \\
\text { SQL Servers, } \\
\text { Visual Basic }\end{array}$ & \\
\hline & This is an open access article under the CC BY-NC license. \\
\hline \multicolumn{2}{|l|}{ Corresponding Author: } \\
\hline $\begin{array}{l}\text { Eko Sumarsono } \\
\text { Program Studi Sistem Informasi, } \\
\text { Fakultas Teknik dan Ilmu Komputer, } \\
\text { Universitas Potensi Utama } \\
\text { Email: eko.sumarsono@gmail.com }\end{array}$ & \\
\hline
\end{tabular}

\section{Introduction}

Controlling the amount of inventory value is not an easy thing for companies, starting from recording the purchase price of goods, determining prices to presenting the inventory in financial statements. The same thing is needed by PT. Source of Mutual Sustenance. Companies engaged in the distribution of food products also need a decision support system that can control inventory so as to facilitate the process of controlling inventory. Previously, inventory at PT. Sumber Rezeki Bersama experienced problems where the company did not prioritize ordering goods, especially those with the highest sales. So that when there are many orders from consumers for these goods, the company cannot fulfill orders on time,

Some of the problems above are summarized into the formulation of the problem in this study, namely how to design and build a system that can help PT. Sumber Rezeki Bersama in controlling the amount of inventory for each item and prioritizing ordering the most sold items (the highest selling items) also speeds up the decision-making process in prioritizing ordering certain items so that consumer goods orders can be realized quickly and accurately. So with this problem, a special application is needed that can make it easier for companies to determine the priority of goods in fulfilling inventory using the AHP (Analitycal Hierarchy Process) method. 
The AHP method is used because it can choose conflicting criteria so that from these existing criteria it will be processed by the AHP method to produce one of the desired alternatives (Nurhidayat, 2013) (Ningrum, 2020). The working principle of AHP is the simplification of a complex, unstructured, strategic, and dynamic problem into its parts, and arranged in a hierarchy (Gunawan, 2014) (Dianawati, 2015). Then the level of importance of each variable is given a numerical value subjectively about the relative importance of that variable compared to other variables. From these various considerations, a synthesis is then carried out to determine variables that have a high priority and play a role in influencing the results of the system (Nurhidayat, 2013) (Isnian \& Suaidah, 2016).

This study aims to build a decision support system for inventory control using the AHP method and can be further developed so as to provide convenience for the user and can assist in making inventory control decisions. And can display inventory reports according to certain criteria.

The benefits that will be obtained are that it will help the company in making decisions for inventory control. It also speeds up the decision-making process in inventory control. And the creation of an easy-to-use system in the inventory control process.

\section{Method}

\subsection{Waterfall Method}

Method is a systematic way or technique to work on a case (Alawiah, 2017) (Ade, 2018). Data analysis techniques in making software use the Waterfall software paradigm, which includes several processes, which can be seen in Figure 1:

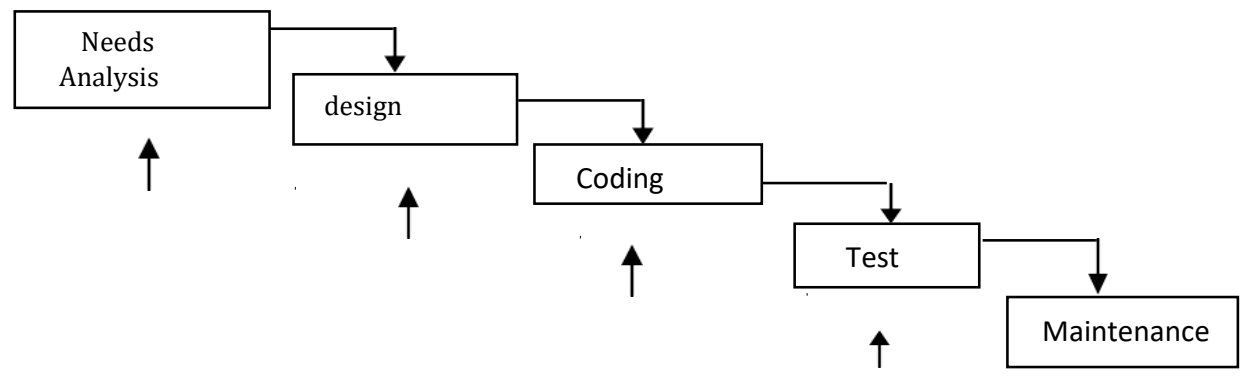

Figure 1.Waterfall Method

The waterfall model is a classical model that is systematic, sequential in building software. This model takes a systematic and sequential approach. It is called a waterfall because the stages that are passed must wait for the completion of the previous stage and run sequentially (Pressman, 2010) (Widianto, Pratama, \& Laksmi, 2020).

The steps that must be taken in the Waterfall methodology are as follows:

a. Software requirements analysis

The requirements gathering process is intensified and focused, particularly on software. To understand the nature of the program being built, software engineering (analysis) must understand the information domain, behavior, performance and interface required.

b. Design

Software design is actually a multi-step process that focuses on four distinct attributes of a program: data structure, software architecture, interface representation and procedural (algorithm) details.

c. Coding

Coding is the translation of a design into a language that can be recognized by a computer. Programmer will translate transaction requested by User. If the design is done in a complete way, the code generation can be done mechanically. To be understood by the machine, in this case the computer, the design must be transformed into a form that can be understood by the 
machine, namely into a programming language through the coding process. This stage is the implementation of the design stage which will technically be done by the programmer.

d. Test

Process Testing is done on internal logic to ensure all statements have been tested. Functional external testing to find errors and ensure that the input will give actual results as required.

e. Maintenance

Maintenance of a software is needed, including development, because the software that is made is not always like that when it is run, there may still be small errors that were not found before or there are additional features that do not exist in the software.

\subsection{Analytical Hierarchy Process (AHP) Method}

Analytical Hierarchy Process (AHP) is an analysis and synthesis method that can assist the decision-making process. AHP is a powerful and accurate decision-making tool because there is a predetermined scale or weight and uses a hierarchy consisting of three levels, namely goals, criteria and alternatives (Abdullah \& Pangestika, 2018) (Jeronimo, 2016).

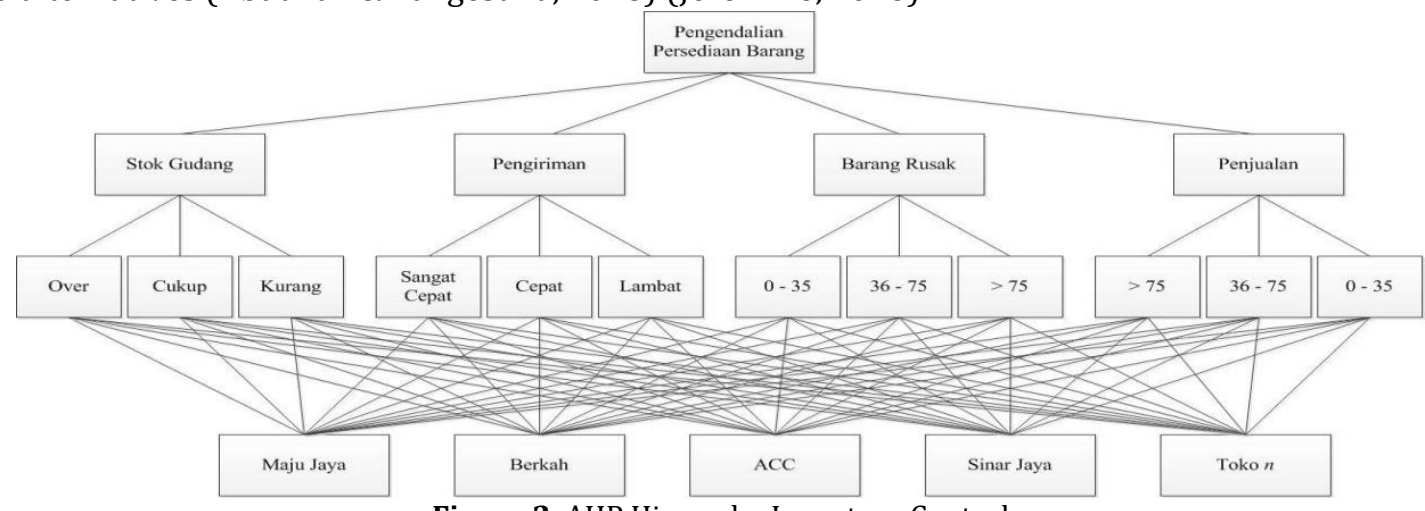

Figure 2. AHP Hierarchy Inventory Control

\section{Results and Discussion}

Based on the results of the analysis and system design that has been done in the previous chapter, it is continued to the implementation level, implementing application programs using programming languages. Implementation is the stage where the system is ready to operate in the actual state. From here it will be known whether the system created can actually produce the desired goals.

The author designed a program for the application of the AHP Method in Inventory Control using the Microsoft Visual Basic.Net programming language using the Microsoft SQL Server database as the result of the program design as follows:

a. Login Form Display

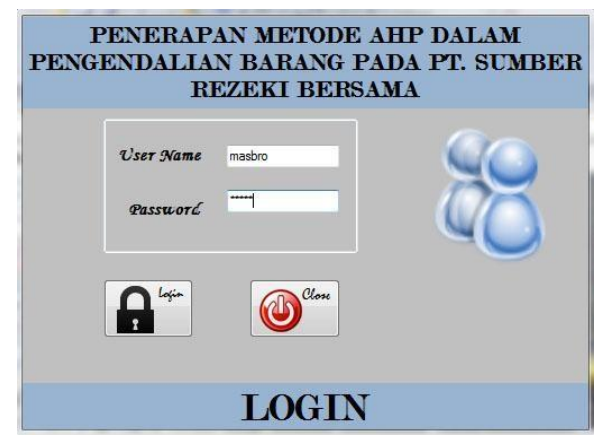

Figure 3. Login Form Display

b. Home Form Display 


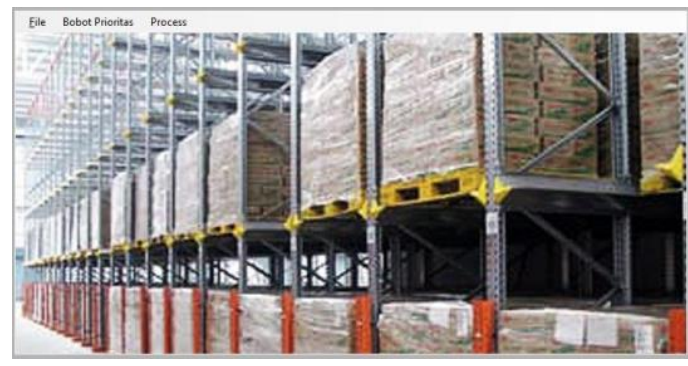

c. Display Login Data Form

Figure 4. Home Form Display

The display of the login data form is a list design from the admin. Serves to display certain forms that act as admin to process important data.

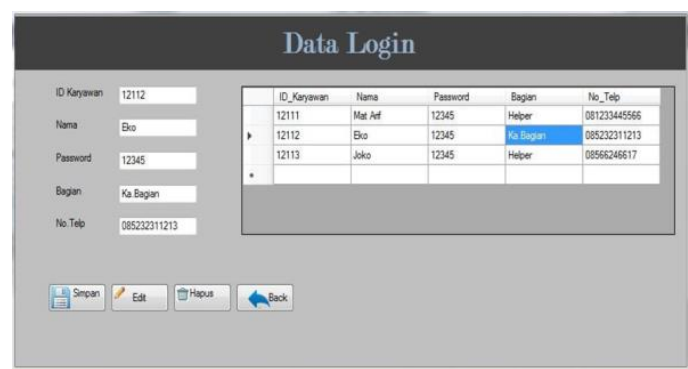

Figure 5. Display Login Data Form

d. Item Data Form Display

The display of the item data form has a function to input the names of the items.

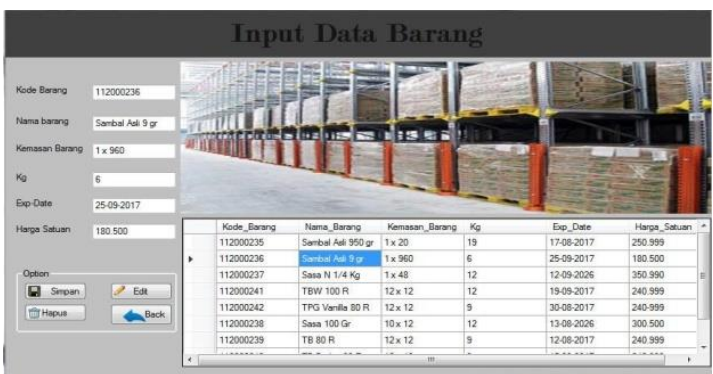

Figure 6. Item Data Form Display

e. Store Data Form Display

The display of the goods layout form has a function to input store names.

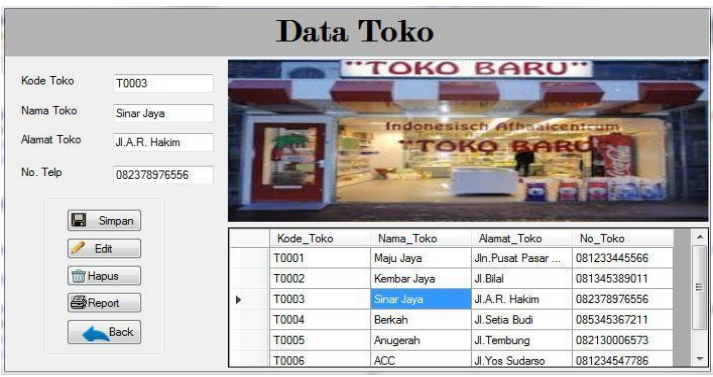

Figure 7. Store Data Form Display

f. Criteria Priority Form Display

The appearance of the criteria priority weight form is the form used to enter the criteria weight value to be processed by the system. 


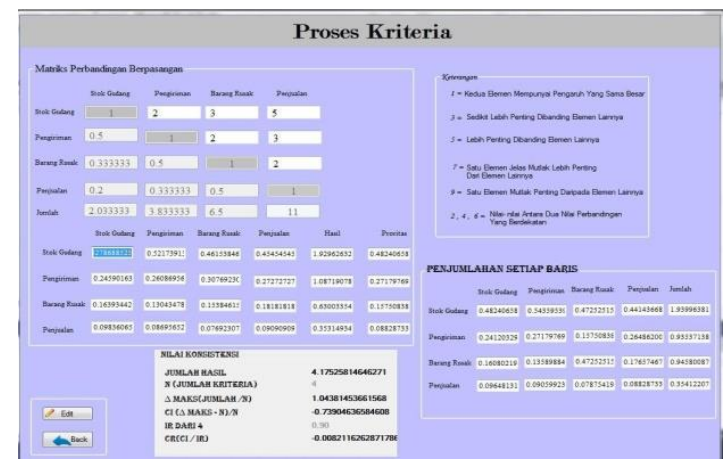

g. Sub-Criteria Priority Form Display

Figure 8. Criteria Priority Weight Form Display

The display of the sub-criteria priority weight form is the form used to enter the sub-criteria weight value that will be processed by the system. If the criteria priority weight form is selected, the sub-criteria weight form screen will appear.

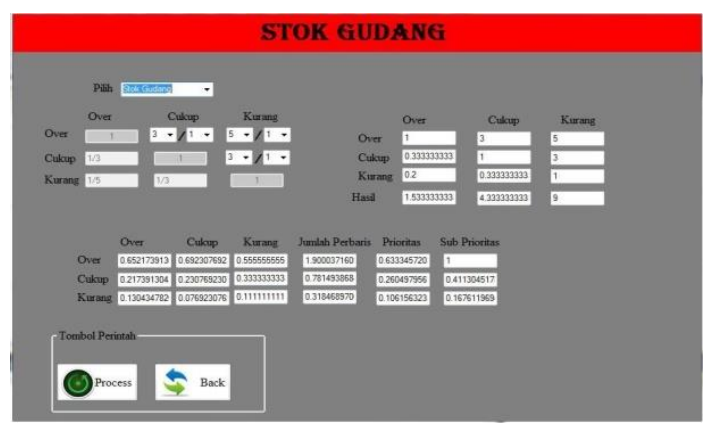

h. Appraisal Form Display

Figure 9. Sub Criteria Form Display

The display of the assessment form is a form used to enter an assessment of the accuracy of the store's stock which will be processed by the system so as to produce decisions and information on good inventory.

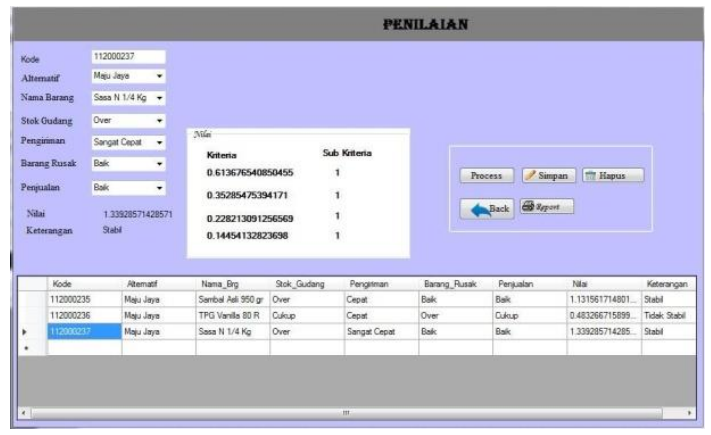

Figure 10. Appraisal Form Display

i. Store Data Report Display

The store data report displays the store names entered by the admin. 


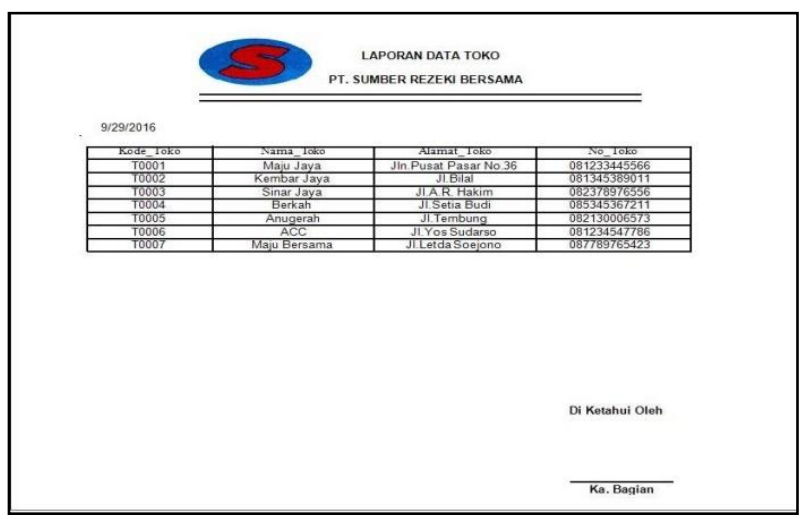

j. Review Report View

Figure 11. Store Data Report Form Display

The assessment report displays the results of the assessment carried out by the admin.

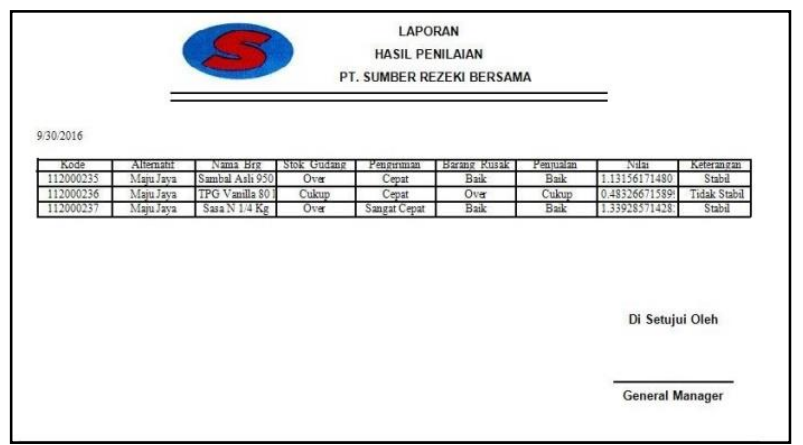

\subsection{Discussion}

Figure 12. Appraisal Report Display

Before the program is used or implemented, the program must first be free from errors. Program errors that may occur include language writing errors, errors during processing, or logical errors. After the program is free from errors, the program is tested by entering data for processing.

TABLES 1.

Store Data System TRial

\begin{tabular}{|c|c|c|c|c|c|}
\hline No & Process Name & $\begin{array}{l}\text { Procedure } \\
\text { Test }\end{array}$ & Input & $\begin{array}{l}\text { Results Yang } \\
\text { Expected }\end{array}$ & $\begin{array}{c}\text { Results } \\
\text { Test }\end{array}$ \\
\hline 1. & Login & $\begin{array}{l}\text { Enter the name and password then } \\
\text { press the login command }\end{array}$ & $\begin{array}{l}\text { Admin Name and } \\
\text { Password }\end{array}$ & Login Success & Success \\
\hline 2. & $\begin{array}{l}\text { Addstore } \\
\text { data }\end{array}$ & $\begin{array}{l}\text { Addstore data then press the save } \\
\text { command }\end{array}$ & Store Data & $\begin{array}{l}\text { The process of } \\
\text { adding store data }\end{array}$ & Success \\
\hline 3. & $\begin{array}{l}\text { Changestor } \\
\text { e data }\end{array}$ & $\begin{array}{l}\text { Changestore data then press } \\
\text { edit command }\end{array}$ & Store Data & $\begin{array}{l}\text { Process of } \\
\text { changing store } \\
\text { data }\end{array}$ & Success \\
\hline 4. & $\begin{array}{l}\text { Deletestore } \\
\text { data }\end{array}$ & $\begin{array}{l}\text { Deletestore data then press } \\
\text { delete command }\end{array}$ & Store Data & $\begin{array}{l}\text { Process of deleting } \\
\text { store data }\end{array}$ & Success \\
\hline 5. & $\begin{array}{l}\text { Print store } \\
\text { data }\end{array}$ & $\begin{array}{l}\text { Print the store data then press the } \\
\text { report command }\end{array}$ & Store Data & $\begin{array}{l}\text { The process of } \\
\text { printing a store } \\
\text { data report }\end{array}$ & Success \\
\hline
\end{tabular}

TABLE 2.

Blackbox Test of Program Algorithm Validity

\begin{tabular}{llll}
\hline Alternative & $\begin{array}{l}\text { Calculation } \\
\text { System }\end{array}$ & Manual & Difference \\
\hline Warehouse Stock & 0.4824 & 0.4824 & 0 \\
Delivery & 0.2717 & 0.2717 & 0 \\
Damaged goods & 0.1575 & 0.1575 & 0 \\
\hline
\end{tabular}




\begin{tabular}{llll}
\hline Alternative & $\begin{array}{l}\text { Calculation } \\
\text { System }\end{array}$ & Manual & Difference \\
\hline Sale & 0.0882 & 0.0882 & 0 \\
Number of Alternatives & 4 Alternatives & \\
Total Difference & $\mathrm{n}$ & 0 \\
Difference Presentation & $0 \times 100 \%$ & $0 \%$ \\
Level & $100 \%-0 \%$ & $100 \%$ \\
Accuracy & & \\
\hline
\end{tabular}

\section{Conclusion}

With the conclusion that can be drawn from a comparison that can finally provide improvements in the future. The conclusion that the authors put forward is, the application that is built is able to handle problem solving in terms of good inventory control for the company. The system that the author built is capable of performing the calculation, inputting, editing and deletion processes. The results of the inventory control decision support system were tested by explaining different criteria by calculating the Analytical Hierarchy Process method. Applications that are built are useful for prioritizing certain items with a fast process.

\section{Reference}

Abdullah, A., \& Pangestika, M. W. (2018). Perancangan Sistem Pendukung Keputusan Dalam Pemilihan Dosen Pembimbing Skripsi Berdasarkan Minat Mahasiswa dengan Metode AHP (Analytical Hierarchy Process) di Universitas Muhammadiyah Pontianak. JEPIN (Jurnal Edukasi Dan Penelitian Informatika), 4(2), 184-191.

Ade, T. A. (2018). Rancang Bangun Aplikasi Pencarian Lokasi Rumah Sakit Bedah Mulut dan Praktek Dokter Gigi Berbasis Android. Universitas Bhayangkara Jakarta Raya.

Alawiah, E. T. (2017). Rancangan Aplikasi Smart City Berbasis Mobile Untuk Meningkatkan Kulitas Layanan Publik Studi Kasus Pemkot Bogor. Jurnal Teknik Komputer, 3(1), 24-29.

Dianawati, E. (2015). SISTEM PENDUKUNG KEPUTUSAN REGROUPING KELAS SMK ISLAM TERPADU (IT) SMART INFORMATIKA SURAKARTA DENGAN METODE ANALYTIC HIERARCHY PROCESS (AHP. STMIK Sinar Nusantara Surakarta.

Gunawan, A. (2014). Sistem Pendukung Keputusan Untuk Perekrutan Karyawan Dengan Menggunakan Metode Ahp (Analytical Hierarchy Process) Study Kasus Pada PT. Valprisma Jaya Abadi, Eprints. Dinus. Ac. Id.

Isnian, A. R., \& Suaidah, Y. T. U. (2016). Sistem Pendukung Keputusan Penerimaan Asisten Dosen Pada Perguruan Tinggi Teknokrat Menggunakan Metode Analytical Hierarchy Process (AHP). Jupiter, 2(1).

Jeronimo, D. S. (2016). Strategi Peningkatan Mutu Pendidikan Di Universidade Da Paz (Unpaz)-Timor Leste Dengan Menggunakan Integrasi Makro Ergonomi Dan Analytical Hierarchy Process (Ahp). Institut Teknologi Sepuluh Nopember.

Ningrum, H. O. (2020). Sistem Penunjang Keputusan Menentukan Tingkat Risiko Klaim Asuransi Industrial All Risk Di PT. Asuransi ASPAN Dengan Metode AHP. Naskah Publikasi Program Studi Sistem Informasi.

Nurhidayat, I. (2013). Faktor-faktor yang berhubungan dengan kejadian dermatitis kontak kosmetik pada penari studio Fantasi di Dunia Fantasi Ancol, Jakarta-Utara tahun 2013.

Pressman, R. S. (2010). The Waterfall Model. Software Engineering: A Practitionerâ€ $€^{T M}$ s Approach, 39.

Widianto, H., Pratama, A. P. P., \& Laksmi, A. P. L. (2020). Pengembangan Aplikasi COSYCALSHIP Berbasis Android untuk Pengelolaan Beasiswa Menggunakan Metode Waterfall. Journal of Advances in Information and Industrial Technology, 2(2), 32-44. 